\title{
The Heyday of the CIO in Iowa: Ottumwa's Meatpacking Workers, 1937-1954
}

\author{
WILSON J. WARREN
}

THE NEW DEAL PERIOD saw the resurgence of organized labor in American politics. The commitment of the Congress of Industrial Organizations (CIO) to industrial unionism sparked much of this revival. CIO organizing efforts strategically tapped segments of America's work force engaged especially in unskilled and semiskilled factory work. Labor historians have typically focused on union-building efforts in large urban areas where African-Americans and first- and secondgeneration Americans from southern and eastern Europe predominated. These groups of workers have also received the most attention from those working-class historians who have more recently been concerned with the sources of dissension that started to undermine industrial unions and their larger political impact in the post-World War II period. ${ }^{1}$

An earlier version of this essay was presented at the 1991 Congress of Historical Organizations, Des Moines, Iowa. I am grateful to Ralph Scharnau for his critique of that paper. Mark L. Smith, secretary-treasurer of the Iowa Federation of Labor, AFL-CIO, graciously allowed me access to and permission to cite the interviews with Ottumwa meatpacking workers included in the Iowa Labor History Oral Project, State Historical Society of Iowa, Iowa City, Iowa.

1. This characterization of the explicit and implicit ethnic and racial emphases of historians of the $\mathrm{CIO}$ applies to much of the older as well as more recent studies in the field. See, for example, Irving Bernstein, The Turbulent Years: A History of the American Worker, 1933-1941 (Boston, 1970); Peter Friedlander, The Emergence of a UAW Local, 1936-1939: A Study in Class and Culture (Pittsburgh, 1975); August Meier and Elliott Rudwick, Black Detroit and the Rise of the UAW (New York, 1979); Nelson Lichtenstein, Labor's War at Home: The CIO in World War II (Cambridge, 1982); Ronald Edsforth, Class Conflict and Cultural Consensus: The Making of a Mass Consumer Society in THE ANNALS OF IOWA 51 (Spring 1992). CThe State Historical Society of Iowa, 1992. 
Workers also organized CIO locals in many of Iowa's industrial communities. Historians have largely ignored Iowa because the profiles of most of the state's industrial cities during the period did not correspond to those of the larger industrial cities in which the CIO took hold. Most of Iowa's manufacturing cities were smaller, most contained only one or two large industries, and they usually did not include significant numbers of new immigrant or nonwhite workers. By examining the evolution of the CIO movement in Ottumwa, particularly at the John Morrell and Co. meatpacking plant, it is possible to assess the origins and eventual sources of conflict in the crucial period from the mid-1930s to the mid-1950s in a portion of America's labor movement that historians typically neglect. ${ }^{2}$

Ottumwa's meatpacking workers formed a packing community out of which they forged a CIO movement during the late 1930 s to early 1940 s. The community was characterized by a closely knit neighborhood and a shared cultural identity. The CIO movement expressed the workers' desire to eliminate the company's "drive" system of supervision and dictatorial managerial control. Workers sought greater participation in the production process partly through collective bargaining. Their solidarity also made it possible to assert their collective power on the shop floor. Finally, they translated the union drive at the plant into a larger political movement that gave the packing community a more powerful voice in the city's politics as a whole.

Flint, Michigan (New Brunswick, NJ, 1987); Gary Gerstle, Working-Class Americanism: The Politics of Labor in a Textile City, 1914-1960 (Cambridge, 1989); and Lizabeth Cohen, Making a New Deal: Industrial Workers in Chicago, 1919-1939 (Cambridge, 1990).

2. James C. Larew's A Party Reborn: The Democrats of Iowa, 1950-1974 (Iowa City, 1980) is one of the very few studies that treats the impact of the CIO and organized labor on the political landscape in Iowa. My forthcoming dissertation, "Working-Class Structural Pluralism and the Limits of the New Deal Order: Midwestern Meatpacking Workers, 1935-1955" (University of Pittsburgh), explores workers' union and partisan political behavior in Omaha, Topeka, St. Joseph, and Ottumwa. I selected these communities so I could focus on their diverse economic and social demographic characteristics. In each community, ethnic, racial, and/or urban-rural conflicts contributed to the limits of meatpacking workers' reform efforts. 
Between 1945 and 1954 class conflict shook the Morrell plant and Ottumwa's politics, as Morrell's management and Ottumwa's business and professional groups offered a unified response to the packing community's challenge to their power. The company adopted new managerial strategies and employment policies designed to strike at the heart of the packing community's solidarity, which eroded considerably after the nationwide United Packinghouse Workers of America (CIO) strike in 1948. Although Morrell did not eliminate the union from the plant, the company and its business and professional allies in the city did curtail the union's power to influence crucial production decisions on the shop floor and blunted much of its citywide political influence. By the mid-1950s, the local union at Morrell no longer embraced a packing community.

DURING THE MID-1930s, Ottumwa's packing workers shared a cohesive class and cultural identity. In addition to a collective neighborhood, cultural, religious, and associational identity, their sense of community had also been shaped by a shared sense of grievance about their position in the city relative to its elites. Ethnicity and neighborhood ties among Ottumwa's packing workers had been evident as early as 1900 . In that year, 60 percent of Morrell's employees were nativeborn of native parents; the remaining 40 percent consisted of mostly second-generation and some foreign-born Americans of English, Irish, Swedish, and German descent. About two-thirds of the packing community resided in the immediate environs of the plant in Ottumwa's east end. These patterns changed little by $1915 .^{3}$

Especially during the 1920s and early 1930s, broader cultural alliances solidified the packing workers' sense of a shared identity. By 1935 almost all of the city's Morrell workers were at

3. The profile of the Morrell work force for 1900 is based on a compilation of information on 1,131 people who worked at the plant between February 1899 and June 1900. The names were gathered from McCoy's Ottumwa City Directory for 1899-1900, the U.S. manuscript census for 1900, and a plant timebook from 1899 (located in box 24, John Morrell and Company Records, Special Collections, University of Iowa Libraries, Iowa City). The profile of the work force for 1915 is based on information gathered on 1,044 Morrell employees listed in the State of Iowa manuscript census for that year. 
least second-generation Ottumwans or native-born Americans of English, Swedish, or German descent who had migrated from the nearby towns and rural areas of south central Iowa. During the 1920s, especially, a large portion of the rural population of south central Iowa migrated to Ottumwa and some other cities of the region. ${ }^{4}$ Many Morrell workers had grown up in farming families or had participated in the small-scale coalmining industry that dotted the region. Of the latter, many brought with them to Morrell prior affiliations with the United Mine Workers. ${ }^{5}$ Morrell's work force consisted in large part of fundamentalist Protestants who attended churches that espoused an evangelical and often millennial Christian message of spiritual conversion. ${ }^{6}$ Only a handful of fraternal orga-

4. Because of the unavailability of census records for the years since 1925, my assessment of workers' ethnicity and nativity in 1935 is based on my surname analysis of a random sample of 127 Morrell employees taken from the 1935 McCoy's Ottumwa City Directory and the information provided by 30 Ottumwa Courier obituaries of Morrell workers who had worked at the plant in 1935 and who died between 1988 and 1991. In my analysis of workers' probable ethnic background, I relied especially on two surname dictionaries, Patrick Hanks and Flavia Hodges, A Dictionary of Surnames (Oxford, 1988), and Eldson C. Smith, New Dictionary of American Family Names (New York, 1973). The population shift from rural to urban areas is suggested by the fact that between 1920 and 1930 the south central counties of Wayne, Lucas, Marion, Mahaska, Monroe, Appanoose, Davis, Wapello, Keokuk, Jefferson, and Van Buren lost 12 percent of their population while Ottumwa's population increased by 22 percent. See Sixteenth Census of the United States, 1940, vol. 1, Population.

5. The connection between coal-mining and meatpacking unions was noted explicitly by Donald Harris, the CIO's Packinghouse Workers' Organizing Committee's first national director, in his interview with Paul Kelso, 8 June 1978, Iowa Labor History Oral Project (ILHOP), State Historical Society of Iowa (SHSI), Iowa City. Additional insight into the importance of former United Mine Workers activists in Iowa's packing industry is provided in Roger Horowitz, "'It Wasn't a Time to Compromise': The Unionization of Sioux City's Packinghouses, 1937-1942," Annals of Iowa 50 (1989/1990), 247.

6. Some insight into the religious identifications of the city's packing workers is suggested by the types of churches established in the city between 1922 and 1939. Nine new churches were established in Ottumwa during these years: the Fundamentalist Baptist Church, Community Christian Church, Chapel of the Church of God, Pentecostal Church of God, Church of the Nazarene, North Church of the Nazarene, Central Addition Pentecostal Church, First Church of the Open Bible, and Harding Park Open Bible Church. Each was situated in predominately blue-collar residential areas. See McCoy's Ottumwa City Directory, 1922; and Polk's Ottumwa City Direc- 
nizations catered to workers, but increasing numbers socialized together in the city's Eagles, Moose, and American Legion lodges. ${ }^{7}$ The bulk of these workers continued to live in the immediate packing neighborhood surrounding the plant. By the 1930s that portion of the city was easily among the most poverty-stricken despite low levels of unemployment among its residents. ${ }^{8}$

Packing workers were painfully aware of the economic gulf that separated them from the Morrell officials who had long dominated the city's elite. Although the English-based company established the Ottumwa plant in 1877, the number of English-born executives residing in the city accelerated after 1888, when Morrell moved its American headquarters to Ottumwa. Workers shared a collective sense of disdain for the life styles and the perceived haughtiness of their supervisors, particularly for the Foster family. Fosters served as top executives of the American branch of the company until 1953. Employees commonly referred to the Fosters and many plant executives as "the rich Englishmen."

tory, 1939. Obituary information for a small sample of 34 workers who worked at Morrell in 1935 indicates that 60 percent had attended a fundamentalist Protestant church. I gathered this obituary information on Morrell workers who died between 1988 and 1991; then I cross-checked their names in the city directory to determine those who were employed at the plant in 1935. I am also extrapolating backward from a sample of 116 obituaries found for Morrell workers who worked at the plant in 1951 and who died between 1988 and 1991. Sixty (52 percent) of these 116 workers were members of fundamentalist Protestant sects.

7. I gleaned this information from my limited obituary samples, based on city directory information on Morrell workers in 1935 and information included in obituaries of former employees in the Ottumwa Courier between 1988 and 1991.

8. See the comparative statistical information on Iowa cities included in E. L. Thorndike's 144 Smaller Cities (New York, 1940), 106-7, 122. A 1936 report from the Iowa State Planning Board, "Housing among the Low Income Groups: Ottumwa," in Iowa Collection, Ottumwa Public Library, provides considerable insight into the disparities in standards of living within Ottumwa itself.

9. Lawrence Oakley Cheever, The House of Morrell (Cedar Rapids, 1948), 88. This collective sense of animosity among Morrell laborers toward the English "caste" (as one worker termed it) of Morrell managerial personnel is striking in the oral history testimony I have gathered over the years. For example, see Ralph Ransom, interview with author, 14 August 1981; Charles Edward Logan, interview with author, 20 July 1981; Donald Schaub, interview with 
Workers directed strong grievances against the company by the 1930s. Although due in part to animosities toward the foreign-born executives living in the city, more crucial were the strains resulting from the company's labor relations policies after 1921. In that year Iowa national guard troops intervened in a violent strike and effectively broke the Amalgamated Meat Cutters and Butcher Workmen (AFL) local formed in 1918. Following the strike, Morrell introduced welfare capitalist measures, providing a thin veneer of managerial reform while actually allowing for harsher methods of worker control undergirded by fear and profanity. President Thomas H. Foster and Plant Superintendent Ernest Manns, though part of the company's management during the paternalistic era preceding World War I, both assumed greater power during the plant's first union period during the war and remained in their respective managerial positions through World War II. Manns, described by one worker as a "hard old Englishman and a horse's ass," set the tone for the new era of labor relations at the plant. Under the guise of a foremen's club, he allowed plant foremen and superintendents greater autonomy to set standards and production methods in their individual departments. By the mid-1930s, each plant department was run autonomously by the plant's mostly English-born supervisors. ${ }^{10}$

THE SOLIDARITY resulting from the shared culture of the packing community, combined with the impetus to unionization provided by the National Industrial Recovery Act (NIRA), infused the union movement that got under way at the Morrell plant in 1933. Workers initially flocked into a revamped Amalgamated Meat Cutters and Butcher Workmen (AFL) Local No.

author, 11 January 1983; Earl F. and Bill Paxson, interview with author, 27 June 1982; and Virgil Bankson, interview with author, 26 September 1982. The quote comes from Bill Paxson, Earl's son.

10. For descriptions of the successful union-building of the immediate postWorld War I years, see Butcher Workman, March 1919, 5; September 1919, 5; and April 1921, 5, 12. On the 1921 packing strike in Ottumwa and Morrell's experiment with welfare capitalism in its Ottumwa plant, see Wilson J. Warren, "The Welfare Capitalism of John Morrell and Company," Annals of Iowa 47 (1984), 501-17. The quote is from Paul Bissell, interview with author, 10 January 1983. Bissell was one of the founders of the CIO movement at Morrell in Ottumwa. 
236, the local that had existed at the plant between 1918 and 1921. Then, in equally large measure, workers rejected that union by 1935 because of the union president's refusal to support a strike at Morrell's other large plant in Sioux Falls, South Dakota. After rejecting help from the Cedar Rapids-based independent packing union movement in 1935-1936, Ottumwa's packing workers then turned for organizational support to the Independent Union of All Workers (IUAW) based in Austin, Minnesota. They did so primarily because the IUAW promised that it was organizing for the CIO, the AFL breakaway organizing committee whose efforts were protected by the federal government's National Labor Relations (or Wagner) Act passed in July 1935. After receiving a union charter from the IUAW in April 1937, Morrell's workers then received a $\mathrm{CIO}$ charter in May and petitioned the National Labor Relations Board for a certification election. When the election votes were counted, the Packinghouse Workers Organizing Committee (PWOC) of the CIO had won in a landslide with two-thirds of the votes. Ottumwa's local received the first packinghouse charter from the $\mathrm{CIO}$, so later it was designated Local No. 1 of the United Packinghouse Workers of America. ${ }^{11}$

11. Butcher Workman, September 1933, 1; Ottumwa Daily Courier, 14 May 1934 and 17 May 1934; Kenneth Ellis and Donald Jones, interview with Paul Kelso, 20 October 1978, ILHOP; Frances Calhoon, Donald Jones, and Virgil Bankson, interview with Leslie F. Orear, 14 January 1974, Local P-1, Amalgamated Meat Cutters and Butcher Workmen of North America, AFL-CIO Records, SHSI; Paul Bissell, interview with author, 25 November 1984; Art Bankson, interviews with author, 17 May 1983 and 25 November 1984; Virgil Bankson, interview with Paul Kelso, 1978, ILHOP; Virgil Bankson, interview with author, 26 September 1982; Minutes of Regular Meetings of 21 April, 3, 17 June, 2 September, 7 October 1936, and 6 January 1937, Mid-west Union of All Packing House Workers (MUAPW), 1936-37 Minute Book, UPWA Local P-3 Records, SHSI; "History of Local No. 32 of Ottumwa, Iowa," CIO Convention Program, p. 15, UPWA Local P-3 Records; The Unionist (official newspaper of the IUAW), 30 April 1937, in "Scrapbook," UPWA Local P-3 Records; and Des Moines Register, 16 May 1937. Although obviously not a unanimous victory, I describe the PWOC's success in Ottumwa's certification election as a "landslide" primarily in the context of the rather narrow victories won by nearly all of the PWOC locals in places such as Omaha, Topeka, and other cities in the Midwest during the late 1930s and early 1940s. For instance, Armour's local in Omaha won with 51 percent, Swift's local in Omaha won with 55 percent, and Morrell's local in Topeka won, after two unsuccessful attempts, with 56 percent. 
The enthusiasm of the union-building period at Morrell flowed from the close-knit and culturally uniform character of the packing community. Before the certification election in October 1937, about 60 percent of Morrell's employees, and 34 of the 70 members of the union grievance committee, lived in the immediate packing neighborhood. The boundaries of this neighborhood corresponded neatly with Ottumwa's Ward One. Another 19 members of the grievance committee lived in Ward Five, immediately adjacent to Ward One. Clearly, workers elected departmental leaders who shared a neighborhood with them as well as worked with them. Union meetings regularly included exhortations from packing neighborhood fundamentalist Protestant ministers, some of whom worked in the plant. ${ }^{12}$

Between 1938 and 1945, Local No. 1 effectively channeled its members' cultural and union solidarity into two types of political action with two objectives. Through collective bargaining and informal job actions, workers hoped to create a more democratic work environment. They also used both types of political action to elevate the status of the packing community in the city as a whole.

Workers' efforts to secure a written collective bargaining agreement commenced shortly after the union had been certified. From January to March 1938, the union threatened repeatedly to strike if the company did not sign a contract including provisions for a closed shop and dues checkoff. Although those demands remained unmet, Morrell legitimized the union by signing a contract with it on March 22, 1938. Then in 1939, the local went out on strike. The union did not win

12. My assessment of the residences of Ottumwa's packing workers is based on a random sample of 127 names from the 1935 McCoy's Ottumwa City Directory. On the early union-building period, see "History of Local No. 32," 15; Art Bankson, interview, 25 November 1984; Paul Bissell, interview, 25 November 1984; Elmer Cline, interview with Merle Davis, 25 September 1981, ILHOP; Regular Meeting of MUAPW, 21 July 1937, 1936-37 Minute Book, UPWA Local P-3 Records; McCoy's Ottumwa City Directory, 1937; The Unionist, 23 July 1937, UPWA Local P-3 Records; and The Organizer, 14, 28 June, 5, 19 July 1937. Insight into the union-building movement in 1937 at the Morrell plant in Ottumwa can also be gleaned from the virtually complete holdings of The Organizer, the plant's union paper in that year, included in the UPWA Local P-3 Records. See also David Brody, The Butcher Workmen: A Study of Unionization (Cambridge, MA, 1964), 167-68. 
much in actual contractual gains, but Morrell did agree to retain all union members. The company did not grant workers the union shop and dues checkoff until the National War Labor Board pressured the company to sign a master agreement with its CIO-organized plants in Ottumwa and Topeka in 1943. In that year, the PWOC received its international union charter from the $\mathrm{CIO}$ and became the United Packinghouse Workers of America (UPWA). ${ }^{13}$

Ottumwa's packing workers were much more successful between 1938 and the end of World War II in securing informal agreements involving production standards. In this respect, Morrell's policy of allowing supervisors to "rule" their departments autonomously played directly into the hands of the union. By directing their solidarity into militant job actions, workers in the two key plant departments, the pork and beef kill and cut, were able to pressure supervisors into new agreements about the pace of the work. These informal arrangements lasted through the end of World War II. ${ }^{14}$

Virgil Bankson recalled one of the most important of those job actions. Clarence "Bronc" Poncy, one of the floorsmen (skinners) in the beef kill, initiated a sit-down strike in the department. Poncy hoped to assert the beef kill workers' power to control the speed of the chain used to regulate how many cattle were killed per hour. Bankson indicated that before the certification of the PWOC local, the company had always

13. I obtained information on the 1938 and 1939 labor disputes primarily from the Ottumwa Daily Courier, especially 19, 20, 22, 25 January, 22 March 1938, 24-30 August 1939. Parts of the UPWA Collection at the State Historical Society of Wisconsin (SHSW), Madison, also deal with the Ottumwa strikes and various contracts signed between 1938 and 1943. See "Agreement, dated 21 March 1938" and "Agreement of John Morrell and Co. and the Packinghouse Workers Organizing Committee, Locals No. 1 and 174," 3 April 1943, box 192, folder 2, UPWA Records. In addition, oral history testimony provides insight into the nature of the controversies in these years. See, for example, Art Bankson, interview with author, 17 May 1983; Virgil Bankson, interview with Paul Kelso; Virgil Bankson, interview with author; Virgil Bankson, interview with Merle Davis, 11 March 1983, ILHOP; Frances Calhoon, Donald Jones, and Virgil Bankson, interviews with Leslie Orear; Tom Cohagan, interview with Paul Kelso, 18 October 1978, ILHOP; Kenneth Ellis and Donald Jones, interview with Paul Kelso, 20 October 1978, ILHOP; and Harold Poncy and Albert Lewis, interviews with author, 8 December 1984.

14. See especially the oral histories cited in n. 13 . 
established the rate. Furthermore, the rate might vary from one day to another. Morrell had generally encouraged a fast pace by paying a "lead-off" floorsman a couple of cents more per hour than the others. Poncy announced one day that this practice would continue no longer, and the rest of the men in the department followed suit. The foremen, especially Leo O'Malley, ridiculed Poncy to keep him moving, but the men refused to budge. Finally, the beef department superintendent, Art Woodman, agreed to talk to Poncy after work. When Poncy brought the whole gang to the meeting, Woodman agreed informally to allow a rate of sixteen beef per floorsman. That pace would remain the accepted standard until after World War II. ${ }^{15}$

While increasing its power in the plant, Local No. 1 aggressively expanded its presence in city politics. Part of this expansion occurred when Local No. 1 created the Ottumwa Industrial Union Council (OIUC) in 1939. Local No. 1 members dominated this $\mathrm{CIO}$ citywide labor body. Although the competing AFL central labor body, the Trades and Labor Assembly, was older and represented more unions, the OIUC soon overshadowed it. The OIUC spurred the establishment of the CIO union in the city's John Deere plant and led attempts to form CIO unions in traditionally AFL sectors, such as the city's truck drivers in 1941. Beginning in 1940, Local No. 1 also regularly began to run candidates for city offices. In the 1940 school board election, the union tried to place a former Local No. 1 president on the board. Although it was not successful, the effort did strike fear in the city's business and professional community when union member Charles Sears ran neck and neck with Ernest Manns, who had been a member of the board for twenty years. ${ }^{16}$

Local No. 1's greatest political victory came during the war years, however. Twice, in 1941 and 1944, the union led coali-

15. Virgil Bankson, interviews; and Harold Poncy, interview. Harold is a younger brother of Clarence.

16. On the school board election, see Ottumwa Daily Courier, 28 February, 1, 3, 12 March 1940. On the struggle between the AFL and CIO to organize the city's truck drivers, see Ottumwa Daily Courier, 2-22 September 1941; and Minutes of Regular Meeting of Local No. 3, 17 September 1941, 1939-42 Minute Book, UPWA Local P-3 Records. 
tions of working-class voters in defeating proposals to institute a city-manager form of government. Beginning in early 1941, the Citizens Committee for the Council-Manager Plan proposed that Ottumwa hire a salaried city manager to "administer the city's business." The city council would then become an unpaid body of public servants. Morrell executives played a leading role in attempting to replace the city's commission system with this new form of government. The advocates of the city-manager plan baldly stated that labor's influence made it impossible to "ELECT and KEEP men of ABILITY in office." The plan's opponents, led by the OIUC, argued that it was a blatant attempt to remove working people from local political affairs. Using language that purposely evoked strong class sentiments in laboring people still struggling for gains in the workplace, opponents asserted that the city-manager plan would mean "ONE-MAN AUTHORITY" and would deprive citizens of "political and personal liberty." Ottumwa's residents, they continued, were being asked to "adopt the dictator plan and have a stranger rule us!" In the union's first political success in the city, the plan failed by a margin of more than two-to-one in the city as a whole and by much wider margins in the working-class precincts. In 1944, after racketeering charges resulted in the dismissal of the city's safety commissioner and nearly ended the mayor's reign, the business and professional community, this time more overtly led by the Foster family, again attempted to secure passage of the city-manager plan. But again, they failed. This time, the vote was just short of a two-to-one margin. ${ }^{17}$

As the packing community's power grew during the war, both Morrell's management and much of Ottumwa's business and professional community organized a counteroffensive. The first and most direct challenge came when Morrell reasserted managerial authority in the plant. Between 1942 and 1947, Morrell introduced a more systematic and centralized approach to its production efforts. A new industrial engineering department initiated time studies, and, immediately after the war, a restructuring of administrative hierarchies gave the plant superintendent greater authority in production decisions. Not coincidentally, many older supervisors, including Ernest

17. See Ottumwa Daily Courier, 7-19 March 1941; and 8 April-21 June 1944. 
Manns, who had been terrors of their departments before the war, retired or were fired during this postwar period. ${ }^{18}$

In 1946 Local No. 1 participated in the UPWA's nationwide strike. The strike was cast locally into the evolving power struggle between the packing community and Morrell. The strike also gave Morrell an opportunity to build alliances with Ottumwa's residents. After ten days of peaceful picketing following the UPWA's strike announcement on January 16, President Harry Truman authorized the government to seize the nation's packing plants. George M. Foster, Morrell's president, solemnly announced on the front page of the Ottumwa Daily Courier that he would run the plant on the government's behalf. The implicit but obvious message was that the company was acting patriotically while the union was not. Still, this bad local press did not dampen the local's sense of triumph. When Local No. 1 voted to return to work three days later, workers received a sixteen-cent-per-hour wage hike, like all UPWA and Amalgamated Meat Cutters and Butcher Workmen (AFL) locals nationwide. ${ }^{19}$

The strike bolstered the union's confidence and further hardened the company's resolve to block any additional union gains. Morrell continued to restructure its management. In the spring of 1947 Charles L. Campbell was appointed to the now crucial position of plant superintendent. A long and diligent student of the "drive" method of supervision, Campbell had

18. Morrell Magazine, March 1944, 8; August 1946, 3; and SeptemberOctober 1946, 9; Harold Poncy, interview; Gilbert Baker, interview with author, 4 August 1982; and John (Jack) Moses, interview with author, 12 September 1982. Both Baker and Moses worked in the industrial engineering department during these years and were involved in the company's more "scientific" approach to production decisions.

19. Ottumwa Daily Courier, 12, 15, 16, 18, 19, 20, 23, 25, 26, 28 January 1946. On the larger context and implications of the 1946 strike for the CIO, see Nelson Lichtenstein, "From Corporatism to Collective Bargaining: Organized Labor and the Eclipse of Social Democracy in the Postwar Era," in The Rise and Fall of the New Deal Order, 1930-1980, ed. Steve Fraser and Gary Gerstle (Princeton, 1989), 122-33. On the meaning and implications of the 1946 strike for the UPWA, see Brody, The Butcher Workmen, 229-32; and Roger Horowitz, "It is Harder to Struggle than to Surrender': The Rank and File Unionism of the United Packinghouse Workers of America, 1933-1948," Studies in History and Politics 5 (1986), 89-90. 
previously held plant superintendent positions in Armour plants in Chicago, St. Joseph, and Kansas City. ${ }^{20}$

From the early 1940s until 1950, Morrell also expanded production at the Ottumwa plant. This expansion was most rapid from 1945 to 1949 , when the number of production workers increased from 2,350 to 3,430. By 1950, the Morrell plant provided almost two-thirds of all the manufacturing jobs in Ottumwa. Significantly, many of the new workers came from outside the city. Whereas in 1935 almost none of the plant's workers resided outside the city, by 1951 about 27 percent of the plant's work force lived in small towns or farms as far away as fifty miles. ${ }^{21}$

UPWA officials were convinced that packers located in rural areas were hiring such people because they would presumably be less interested in union participation. Thus, beginning in 1944, the UPWA extended its political support for Democratic candidates into rural areas. In 1946 they added farmer-labor relations to their list of major programs. The UPWA encouraged locals situated in rural areas to establish their own farmer-labor committees and conduct meetings focusing on issues of concern to rural residents, farmers, and city laborers. Ottumwa formed one of the first such local union committees during the spring of 1947 following the UPWA's successful arbitration of a milk producers' strike in the city. In 1947 and early 1948 Local No. 1 aggressively pursued farmerlabor cooperative efforts in the hope of winning rural support for their overall agenda. ${ }^{22}$

20. Morrell Magazine, May 1947, 5.

21. Packinghouse Worker (UPWA's official newspaper), 14 December 1945, 3; John Morrell and Co. Executive Department Announcement, 16 April 1949, box 411, folder 7, UPWA Records; Seventeenth Census of the United States, 1950, vol. 2, Population. The calculation of rural residents employed by Morrell in 1951 is based on my systematic sampling of plant employees from the Polk's Ottumwa City Directory for that year. Although not perfect, in lieu of employee records, city directories provide substantial insight into workers' residences since their criteria for inclusion are based on who works in the city as well as who lives there. The city directories indicate the city where the employee lived, so it is possible to calculate the distance traveled to work. Some workers commuted from Kirksville, Missouri, about fifty miles south of Ottumwa.

22. The Packinghouse Worker consistently noted the UPWA's farmer-labor political activities after the mid-1940s. See especially Packinghouse Worker, 30 
THE UPWA'S NATIONWIDE STRIKE in 1948 severely tested the solidarity Local No. 1 had built in the face of steady managerial "counterorganizing" efforts during the previous six years. This crucial struggle for power in the plant spilled over into a fierce battle for public support in the rest of the city. Much of the propaganda war was waged in the pages of the Ottumwa Daily Courier.

The packing community demonstrated its solidarity during the early days of the strike by maintaining a picket line six and one-half miles long around the plant. Public officials, fearing that the strikers might become violent, began to plan how to combat them. A few days after the strike began in early March, officials closed all the taverns in the packing neighborhood, citing instances of public drunkenness among strikers. On April 5, Local No. 1 issued a bulletin claiming that Ottumwa Safety Commissioner Charles Carlson was considering the use of fire hoses on picketers since they "would be better than using gun butts." Carlson denied the statement, but quickly added that fire hoses would be used only if a riot broke out. ${ }^{23}$

Because of the unity strikers exhibited in March, Morrell officials decided in early April to test the union's strength by shipping meat out of the plant. Morrell knew that strikers would interpret such an attempt as an initiation of business activity proscribed during strikes by prior agreements. Jim Collins, a foreman who worked in the plant during the strike, later described the company's plan as "an attempt to break the

March 1945, 4-5; and December 1952, 2. Also see "UPWA Program for Building Toward Farmer-Labor Unity," 9 April 1947, box 490, folder 10, UPWA Records. This document offers the union's rationale for initiating the program, reviews its efforts to date, and gives a preliminary assessment of the success of the program. For a sample of the UPWA's evaluation of Local No. 1's farmer-labor efforts, see "A Roundup of What is Happening in Farmer-Labor Relations," c. August 1947, box 298, folder 11, UPWA Records. For more information on the general context of the CIO's farmer-labor political activities in the period (for example, the Farm Equipment Workers were even more active in this field than the UPWA), see Wilson J. Warren, "The 'People's Century' in Iowa: Coalition-Building among Farm and Labor Organizations, 1945-1950," Annals of Iowa 49 (1988), 376-78.

23. Ottumwa Daily Courier, 15, 19, 31 March, 1, 2, 5 April 1948. On the national dimensions of the 1948 UPWA packing strike, see Brody, Butcher Workmen, 232-40; and Roger Horowitz, "It is Harder to Struggle than to Surrender,'" 90-93. 


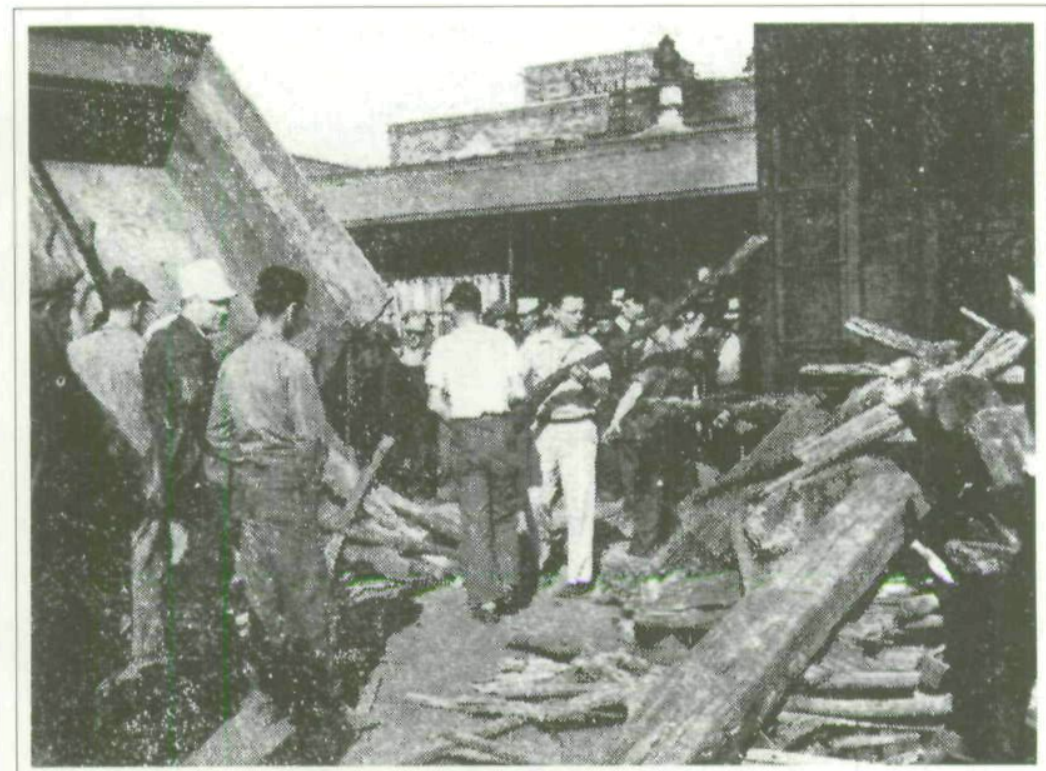

Picketers build a barricade to prevent the movement of a freight car stopped the previous day. Ottumwa Daily Courier, 7 April 1948.

union by shipping meat out." When Morrell officials attempted to move five railcars loaded with meat out of the plant on April 7 and 8 , massed picketers successfully blocked the cars from leaving. On April 9, however, Iowa District Court Judge Harold V. Levis issued a temporary injunction that thoroughly undercut the massed unity the strikers had demonstrated. The injunction stipulated that just five people could picket at each picket station (instead of the dozens who had done so previously), and that strikers could not barricade plant entrances and exits or impede employees entering or leaving the plant. In addition, the injunction named 220 union activists who could be charged with contempt if any of the injunction's restraints on picketing the plant were violated. ${ }^{24}$

Apart from painting the words SCAB MEAT on the side of some of the railcars involved in the attempt to move meat out of the plant, Ottumwa's packing community had not engaged in any violence before April 9. The injunction changed the strikers' tactics, however. Because of this legal restraint, Local No. 1

24. Ottumwa Daily Courier, 6-10 April 1948; Collins, interview with author, 12 August 1981. 


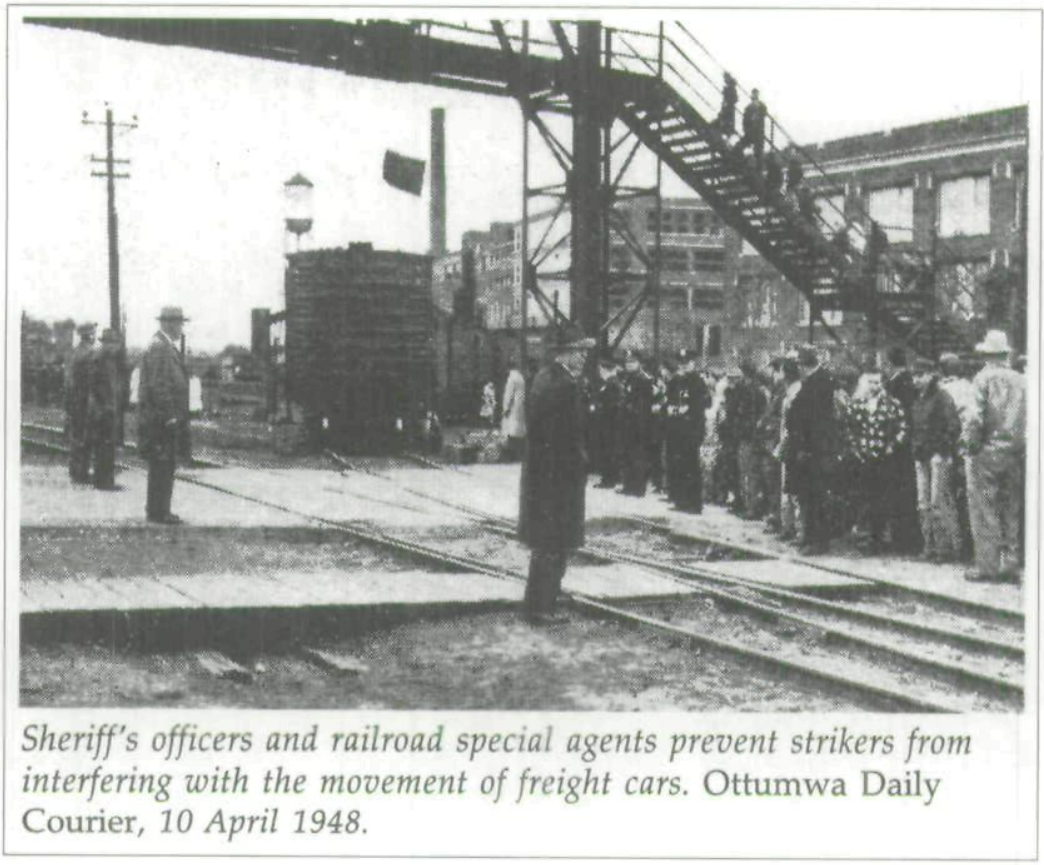

embarked on a type of "guerrilla warfare" to forcibly dissuade foremen and other supervisors, the only employees the company could persuade to process meat, from carrying on such activities. Strikers either verbally or physically assaulted managerial personnel involved in production during the strike. Typically, strikers would follow foremen and supervisors when they left the plant, and attack them at or near their homes. Virgil Bankson later explained that such "violence was necessary" from the union's perspective; union leaders now felt that they were involved in a life-and-death struggle to save their union. From their perspective, it was the company that had violated earlier agreements by attempting to initiate business activities during the strike. Under the restraint of the injunction, union leaders could not bring the strength of the packing community's solidarity to bear against the company. They therefore condoned a type of "directed" violence in the hope of maintaining their strike effort. This type of violence differed from the random violence that broke out in other midwestern packing centers during the 1948 strike. In Omaha, for instance, union leaders made little concerted effort to have strikers strategically 
direct their violence. Instead, union members committed random acts of violence that four major UPWA local unions and their leaders could not control. ${ }^{25}$

Morrell quickly responded to this guerrilla warfare by targeting for prosecution Local No. 1 leaders who had participated in such violence. On April 15, Donald Jones, Local No. 1's president in 1947, was arrested for contempt of the injunction. Jones had allegedly participated in an attack on three foremen. During the following week, four rank-and-file members were arrested on similar charges, but Morrell pressed charges only against Jones. Iowa District Judge Harold V. Levis heard evidence in the Jones contempt case from April 21 to 27. In the meantime, Levis added an additional 255 strikers' names to the injunction. While the Jones case was under way, the Ottumwa Daily Courier left no doubt about its stand on the actions of Jones and fellow strikers. "Evidence is multiplying that lawless goon squads are patrolling the city streets and neighboring highways to terrorize persons connected with John Morrell and Co." Morrell officials, as well as growing segments of the business and professional community, were now adamant that the union's ranks were filled with thugs who condoned criminal activity. The union's opponents charged that its workers were not only lawbreakers; they were lazy as well. President George M. Foster publicly proclaimed, "Our experience with the Ottumwa local has been bad. Within the past five years [roughly coinciding with the beginning of the new managerial policies] there have been 42 work stoppages, slowdowns, or strikes resulting in 67 days lost." 26

25. Virgil Bankson, interview with Paul Kelso. In comparing the use of violence by strikers during the 1948 UPWA strike, my remarks are based primarily on a systematic comparison of the 1948 strikes in Ottumwa, St. Joseph, Topeka, and Omaha, detailed in my forthcoming dissertation. On the 1948 strike in Omaha, see also William Pratt, "Workers, Bosses, and Public Officials: Omaha's 1948 Packinghouse Strike," Nebraska History 66 (1985), 294313. More specifically, my assessment of the use of violence by strikers in Omaha is based on UPWA local union records included in the UPWA Records, State Historical Society of Wisconsin, Madison; Omaha newspapers, especially the Morning World-Herald; and the interviews with Omaha union members included in the UPWA Oral History Project, State Historical Society of Wisconsin.

26. Ottumwa Daily Courier, 15, 16, 21, 22, 23 April 1948. 
In this emotionally charged atmosphere, the packing community's perspective on the strike and its conduct was increasingly isolated. Ottumwa's packing workers were by no means alone in this respect. Nationally, organized labor's power and prestige were in retreat by 1948, particularly following the passage of the Taft-Hartley Act in 1947. Although historians have since downplayed the effect of the act's restrictions on labor, there is little doubt that both the AFL and CIO then saw it as a blow to their strength. ${ }^{27}$

Locally, the isolation of the packing community was reflected in Judge Levis's decision against Donald Jones. Two other strikers present at the altercation, Jim Hammersley and Bernard Jones, Donald's brother, testified that Donald Jones was not involved in the fight. In fact, both men attested that they verbally confronted one of the foremen, Claude Smith, after he got out of a car that had stopped at the home of another Morrell supervisory employee. Smith then struck Bernard Jones with a flashlight. Smith's assault only prompted both men to attack Smith. Of the nine other foremen present at the scene, only one corroborated Smith's claim that Donald Jones was involved in the fight. Yet on April 28, Judge Levis found Jones guilty of contempt and ordered him to serve sixty days in the county jail. Levis's reasoning in his decision is particularly revealing.

The circumstances surrounding the whole affair lead to the conclusion that the mission of the occupants of the two cars which followed the Morrell car for a distance of four or five miles across the city was not a peaceable one, but rather, it appears that the occupants of the two cars were acting in concert to follow the Morrell car until it stopped for the purpose of using coercion, intimidation and force upon its occupants.

Levis continued that the union men "must have rushed almost en masse to the door of the Morrell car" (emphasis added). The resulting confusion would account for the contradictions in the

27. One of the most respected scholarly assessments of the Taft-Hartley Act can be found in Christopher L. Tomlins, The State and the Unions: Labor Relations, Law, and the Organized Labor Movement in America, 1880-1960 (Cambridge, 1985), 247-316. 
foremen's testimony about Jones's participation in the fight. Jones himself repeatedly insisted in interviews conducted over the following twenty-five years that he had not participated in the fight. Nevertheless, the Iowa Supreme Court upheld Jones's conviction on April 11, 1949, but reduced his sentence to thirty days. The message was clear: public order as interpreted by the company and state and local officials must prevail despite the packing community's perception that their avenues of acceptable action had been undercut by the injunction. ${ }^{28}$

After the beginning of May, the company had greater success in attracting replacement workers. In a list compiled in 1950 to prevent their employment at the plant, Local No. 1's records showed that just seventy-two active union members crossed the picket lines, while an additional 139 nonunion members worked in the plant before the strike ended. To be sure, the number of scabs was small. Still, the backgrounds of the replacement workers provide some insight into the sources of dissension growing within the local union. Based on information on the addresses of sixty-two union members who crossed the picket lines, the largest segment (37 percent) lived at rural route addresses or in small farming towns. In comparison, although it was still home to by far the largest number of plant workers, the immediate packing neighborhood surrounding the plant contributed only 16 percent of the scabs. ${ }^{29}$

The only other significant difference between the urban and rural workers was that the rural component did not participate to nearly the same extent in the four largest social organizations for working people in the city: the Eagles, Moose, American Legion, and Veterans of Foreign Wars. ${ }^{30}$ As had

28. Ottumwa Daily Courier, 27, 28 April, 8 May 1948; Kenneth Ellis and Donald Jones, interviews with Paul Kelso; Frances Calhoon, Donald Jones, and Virgil Bankson, interviews with Leslie Orear; and Edward Filliman, UPWA field representative, Weekly Report, 12 February and 16 April 1949, box 411, folder 7, UPWA Records.

29. "Addresses of Union Scabs in 1948," box 23, folder 2, Local P-1 Records, SHSI.

30. This observation is based on a work force profile developed for Morrell workers who were employed at the plant in 1951. Using information included in obituaries in the Ottumwa Courier between 1988 and 1991, supplemented by information on these workers provided by the 1951 Polk's Ottumwa City Directory, I developed profiles for 116 deceased Morrell work- 
already been the case in the 1930s, the packing community situated in the immediate plant environs provided considerable membership in the fraternal organizations that catered to working people in Ottumwa. (The VFW drew significant numbers only after World War II.) Although the content or programs of these fraternals was not overtly political, they functioned as part of the packing community's range of social ties, both formal and informal, that contributed to its solidarity. The importance of Morrell workers in these fraternals was evident during the 1948 strike when the American Legion post's membership voted to donate $\$ 1,500$ to Local No. 1's strike fund. Even though a slightly higher percentage of the rural component's males were veterans of World War II, few of them were willing or able to travel to Ottumwa to belong to the local American Legion or VFW posts. Morrell workers apparently hoped to tap the American Legion as an additional source of financial aid. However, the executive board of the post, which was dominated by business and professional allies of the company, turned down the membership's request. ${ }^{31}$

Whereas the urban component of Morrell's work force was knit closely not only by membership in Local No. 1 but also by a wider circle of social affiliations, this broader social participation was largely absent from the rural components of the work force. Thus, while Local No. 1's leaders had attempted to educate and incorporate the farmers and working-class rural resi-

ers who had worked in the plant in 1951. Whereas 31 (27 percent) lived at rural or small-town addresses in that year, the other 85 (73 percent) lived in Ottumwa. Typically, the Courier's obituaries provide consistent and detailed information about workers' ages, marital status, veteran status, and religious affiliations as well as lists of their memberships in various social organizations. In terms of birthplaces, 72 percent of the urban component had been born in either Wapello County or adjacent counties versus 87 percent for the rural component. Regarding marital status, 86 percent of the urban proportion were married, while 81 percent of the rural workers were married. The largest segments of both groups were members of fundamentalist Protestant sects ( 54 percent for the urban, 45 percent for the rural), and almost one-half of both groups' males were veterans of World War II (43 percent for the urban, 48 percent for the rural). These small differences contrast with those marking the difference between the two groups on other social memberships: 54 percent of the urban workers belonged to one or more social organizations compared to only 29 percent of the rural workers.

31. Ottumwa Daily Courier, 12, 26 May 1948. 
dents of the area into its culture of solidarity before 1948, these people were not enmeshed in the broader network of social relations that undergirded this culture. Accordingly, they were not sensitive to the traditions and concerns that had prompted the packing community's successful union-building. These attributes help to explain the greater propensity of rural workers to cross the picket line during the strike. ${ }^{32}$

On May 27, Local No. 1 voted to end its participation in the UPWA's strike and settled according to terms set by the company. The 1948 strike was a key turning point in the evolution of the packing community's political solidarity in Ottumwa. Although superficially the local emerged from the strike intact, the packing community would now be on the defensive. Its solidarity was increasingly disrupted not only by even more aggressive company strategies in dealing with the union, but by the company's continued employment of rural workers. Morrell also learned to count on support for its positions from Ottumwa's business and professional community after the 1948 strike. Morrell had successfully raised the specter of persistent meat famines and continuing declines in the city's retail business if such strikes occurred again. Such threats carried considerable weight in Ottumwa, since 75 percent of the meat sold there in 1945 came from the Morrell plant, and retail business declined by 50 percent in the town during the two-month strike in $1948 .{ }^{33}$

32. The obituary data suggest that a large number of the rural workers who were increasingly employed by Morrell at this time had had some farming experience. Although the available literature on the impact of the growing influx of farmers and part-time farmers into Iowa factories in the immediate postwar period is slight, there have been a few studies on the characteristics of lowa farmers who quit farming in the decade of the 1950s and who found urban employment. See, for example, Jeffrey Allan Robinson, "Perceptions and Experiences of Young Iowa Farm Families who Changed Residence and Occupation" (M.S. thesis, Iowa State University, 1962); and William Marion Edwards, "Occupational Adjustment among Iowa Farm Operators" (M.S. thesis, Iowa State University, 1971). Typically, such "quit" farmers were likely to be tenant farmers. According to Robinson (p. 24), between 1940 and 1959 the number of tenant farmers in Iowa dropped by forty thousand.

33. In assessing the aftermath of the 1948 strike for the UPWA, David Brody, The Butcher Workmen, 235, says, "The central fact was that the crushing defeat and internal breakdown did not destroy the UPWA; recovery was quick and convincing." In Ottumwa's case, however, Local No. 1's postwar experiences 
MORRELL'S STRATEGY in fighting the union in the plant from 1949 to 1951 involved a persistent refusal to recognize Local No. 1's right to contest production decisions made by the company. Specifically, Morrell introduced "job load" changes; that is, the company decreased the number of workers in various departments while increasing the pace of production. These changes were established in the wake of time studies undertaken by the company's industrial engineering department and were enforced by Plant Superintendent "Mad Dog" or "Do It or Else" Campbell (as the union now referred to him). The changes occurred primarily in the union strongholds of the beef and hog departments, where they undermined the informal production arrangements the union had established before the end of World War II. Between 1949 and 1951, Morrell repeatedly refused to bargain with either Local No. 1 or international representatives of the UPWA on the issue of production decisions related to job loads. When the local called strikes, walked out, or stopped work over company refusals to listen to their side, the company not only suspended hundreds of workers but regularly used the pages of the Ottumwa Daily Courier to publicize the union's alleged refusal to perform "a fair day's work for a fair day's pay." 34

In the face of the company's increased resolve after the 1948 strike to disrupt collective bargaining and reshape com-

belie his statement. The statistic on the contribution of local Morrell meats to Ottumwa's retail market is from Ottumwa Daily Courier, 6 April 1945; that for the decline in retail business is from ibid., 4 May 1948. On the negotiations between labor and management leading up to the decision of Local No. 1 to return to work, see Ottumwa Daily Courier, 5, 7, 10, 14, 22, 28 May 1948.

34. The sources for the contest between the union and Morrell between 1949 and 1951 over production-related issues include Morrell Magazine, National Provisioner (the meatpacking industry's periodical), and Ottumwa Daily Courier, all of which were "mouthpieces" for the company's side, and, for the union, The Bulletin (Local No. 1's official paper), Packinghouse Worker, and Edward Filliman's weekly reports to the UPWA international office. See especially Morrell Magazine, December 1948, February 1949, and April 1952; National Provisioner, 17 December 1949; Ottumwa Daily Courier, 23 February, 1 May 1949, 24, 26 March 1951; The Bulletin, 15 April, 2, 16 May, 6, 20 June, 13, 18, 25 July, 15 August, 19 September 1949, box 411, folder 7, and box 441, UPWA Records; and Packinghouse Worker, 1 October 1948 and 9 September 1949. A nearly complete set of Edward Filliman's UPWA field representative reports from 1949 to 1951 are included in box 411 , folder 7 (1949 reports) and box 415, folder 13 (1950-51 reports), UPWA Records. 
munity attitudes, the local attempted over the course of the next three years to recapture its prestrike aggressiveness in combating the company. The union adopted a concerted policy of attacking Morrell as an enemy of all working people in Ottumwa. Noting that after the speed-ups in 1949, seventyfive workers produced as much as one hundred workers had ten years earlier, The Bulletin, Local No. 1's weekly paper, proclaimed, "John Morrell and Company will ruin your health and drive you to your grave 15 years ahead of time. John Morrell and Company is our common enemy. Let's concentrate on an all-out effort to defeating [sic] them." Morrell responded to such attacks in what was now their typical post-World War II style: they took out a newspaper advertisement. In reply to the union's outburst, the company rhetorically asked Local No. 1 in a quarter-page advertisement to explain what it meant when it said that it wanted to "defeat" the company. "Where will you workers go if the company is put out of business?" Local No. 1 noted in its own (smaller) ad that, as usual, the company's remarks were meant for public consumption and confused the issues. Although Morrell had praised Local No. 1 for their "magnificent job" during the war, now, even though overall production had increased, workers were told that the company expected a fair day's work for a fair day's pay! "If the company was fair minded and believed in humanity, they would sit down and work out some fair agreement [involving job loads]." ${ }^{\prime 35}$

Although initially aggressive on these issues, by 1951 a combination of financial turmoil, weakening resolve by the local union's leadership, and decreasing support from the international union's leadership combined to sap Local No. 1's ability to contest the company on production-related issues. Edward Filliman, the UPWA international representative assigned to the plant, and a former union leader there during the local's heyday, noted in 1951 that the company continued to hire new workers from outside the city. Those new workers presumably replaced workers who had participated in the

35. The Bulletin, 15 April 1949, box 411, folder 7, UPWA Records; John Morrell and Co., Executive Department Announcement, 16 April 1949, box 411, folder 7, UPWA Records; newspaper clippings in box 441, folder 7, UPWA Records; and The Bulletin, 2 May 1949, box 441, UPWA Records. 
union-building ten to fifteen years before. Thus Filliman found that he had to reeducate the local about the need for solidarity. Moreover, between 1949 and 1951, when Local No. 1's farmerlabor relations program could have helped immensely, it nearly disintegrated. Filliman also chastised the international union leaders for not supporting the local's fight, which resulted in eighty-eight separate walkouts at the plant in 1951 alone.

You may say [that continued walkouts are] not justified, but I say the men were right. I helped break down this kind of [arbitrary work] assignment and condition years ago. [This] was one of the big deals when we organized our union[.] [T]his is a fighting deal, this old company method of do as your [sic] told was one of the things that brought on unionism.... [We] have to fight to keep from going back to those days again. ${ }^{36}$

After 1948, Local No. 1's political power in the city also eroded considerably. Early in 1949, Local No. 1, operating in concert with the Ottumwa Industrial Union Council and the AFL's Ottumwa Trades and Labor Assembly, formed the Ottumwa Policy Committee to unite the city's working class for the approaching city elections. Local No. 1 hoped to punish officials who had taken the company's side in the 1948 strike as well as to reestablish their political prestige in the city. Three candidates supported by the Ottumwa Policy Committee made

36. Edward Filliman, weekly field reports, September 1951; see also 6 January, 21 April, 18 August 1951, box 415, folder 13, UPWA Records. The statistic on work stoppages in 1951 is from National Provisioner, 1 May 1954. Part of the reason for the decline of Local No. 1's farmer-labor program was the dissolution of the UPWA's overall farmer-labor relations program following the death of its first national director, Lee Simon. Between 1949 and 1952, the UPWA continued to sponsor booths at county fairs throughout the Midwest, but these efforts were seen even with the UPWA as inadequate means of addressing the need to sway "anti-labor" farmers and rural residents who worked in packing to the union's side. See especially "UPWA Farmer-Labor Program: Present Position and Future Prospects," 4 October 1948, box 50, folder 9, UPWA Records; Russell Bull (UPWA District No. 3 assistant director) to UPWA Local Unions Nos. 1, 3, 31, 38, 46, 79, and 89, 29 October 1948, box 490 , folder 11, UPWA Records. By late 1952, Clive Knowles, UPWA farmerlabor director, acknowledged that the UPWA's farmer-labor relations program had reached a "standstill." Knowles to Russell Lasley, UPWA vicepresident, 24 November 1952, box 488, folder 6, UPWA Records. See also Warren, "The 'People's Century' in Iowa," 387. 
it onto the general election ballot. Before the general elections, Local No. 1 reminded its members to "recall just what position certain members of the City Council took in regards to the strike action at Morrells last year." Yet just before the election, the Ottumwa Policy Committee's alliance between AFL and $\mathrm{CIO}$ unions disintegrated. The Ottumwa Trades and Labor Assembly told its AFL members to support the three candidates running in opposition to those that Local No. 1 and the Ottumwa Industrial Union Council were supporting. One of the candidates supported by the AFL was Herschel Loveless, a future Democratic governor of Iowa. In the largest voter turnout for city elections in Ottumwa's history, only one of the candidates supported by Local No. 1 emerged victorious. ${ }^{37}$

Then, in the 1951 and 1953 city elections, none of Local No. 1's candidates who ran for office even received enough votes in the primaries to make it onto the general election ballot. Indeed, in those years, the packing community did not give undivided support to its own people. This may have been because the candidates were local union officials embroiled in financial problems that disrupted the local during the early 1950 s. Undoubtedly exasperated over the multitude of problems the local was experiencing, Edward Filliman noted in one of his weekly reports in 1951 that too many of Local No. 1's officers were "Do-Nothing, Money-Grabbing individuals." In addition, just one of the dozen Local No. 1's executive board members in 1951 had taken a leading role in the union-building that had occurred in the 1930 s and early 1940 s. $^{38}$

The final blow to the packing community's political power in Ottumwa fell in 1953 when the council-manager plan of city government finally replaced the commission form. Defeat of the plan had been one of the local's greatest triumphs in 1941 and 1944. Yet in 1953, after Local No. 1's executive board refused to allocate more than a paltry sum to fight it, it passed

37. Ottumwa Daily Courier, 12, 23 February, 14, 16, 28, 29 March 1949; The Bulletin, 24, 28 March 1949, box 441, UPWA Records.

38. On the 1951 and 1953 city elections, see Ottumwa Daily Courier, 14, 27 March 1951, 21 October, 4 November 1953. Filliman's quote is from his UPWA weekly report, 10 February 1951 , box 415, folder 13, UPWA Records. On the turnover in Local No. 1's executive board by 1951, see Local No. 1 Officer List, 8 February 1951, box 314, folder 2, UPWA Records. 
by a 58 percent plurality. Only in the precinct including the immediate packing neighborhood was the plan defeated; Morrell workers in precincts outside the old packing neighborhood contributed to its passage. Furthermore, not one $\mathrm{CIO}$ member in the city was able to win a seat on the new city council when elections were held in the fall of that year. The Ottumwa Industrial Union Council's efforts in promoting candidates were easily pushed aside by a "Good Government Association" consisting mostly of business and professional members. ${ }^{39}$

JOINT UNION-COMPANY SPONSORSHIP of a monthlong "Morrell Days" celebration in April 1954 symbolically demonstrated the erosion of the packing community's political power in Ottumwa. The celebration was meant to provide a focal point for the initiation of a new spirit of cooperation among Morrell, Local No. 1, and the city of Ottumwa. Not only did the union support the new posture of "cooperation," but Local No. 1 President Louis Crumes announced that the union would now be at the forefront of "Morrell boosting." The union had demonstrated this new commitment by not having called a single walkout over production decisions in the plant since October $1953 .{ }^{40}$

To be sure, Local No. 1 continued after the early 1950s to fight for improvements in workers' wages and benefits, and it regularly mobilized its membership behind pro-labor candidates for local, state, and national offices. Thus, for instance, Local No. 1 garnered considerable rank-and-file support in 1952 and 1956 for Democrat Herschel Loveless's bid for the Iowa gubernatorial seat. The local's push for Loveless was

39. Ottumwa Daily Courier, 29 April, 27 July, 21 October, 4 November 1953. Information on Local No. 1's lack of financial commitment to the councilmanager city government issue comes from Local No. 1, 21 July 1953 Membership Meeting, Minute Book, October 1952-February 1955, Local P-1 Records, SHSI.

40. Morrell Magazine, January and April 1954; Local No. 1, 22 March 1954 Special Executive Board Meeting, Minute Book, October 1952-February 1955, Local P-1 Records; National Provisioner, 21 August 1954; Cheever, The House of Morrell, 137. 
ironic given their rejection of him during the 1949 city council campaign. ${ }^{41}$

Despite their continued economic successes and their commitment to liberal politicians, by the mid-1950s Local No. 1's earlier goals of increasing worker participation in the company's production decisions and extending the direct influence of the packing community into the city's politics were no longer tenable. Local No. 1's efforts in those areas had been successfully thwarted after 1945 by the company and a politicized business and professional class in Ottumwa. By the mid-1950s, Local No. 1 no longer embodied the packing community from which it had originally arisen.

41. In 1952 Loveless won a 72 percent plurality in the city's first precinct, site of the now eroded immediate packing neighborhood, though he failed to carry the election in the state. Four years later, when he was victorious, Loveless won a 74 percent plurality in Ottumwa's first precinct while taking 59 percent of Wapello County's vote. See State of Iowa, Official Register, 19531954 (Des Moines, 1953), 380-83; and State of Iowa, Official Register, 19571958 (Des Moines, 1957), 412-13. 
Copyright of Annals of Iowa is the property of State of Iowa, by \& through the State Historical Society of Iowa and its content may not be copied or emailed to multiple sites or posted to a listserv without the copyright holder's express written permission. However, users may print, download, or email articles for individual use. 